\title{
Use of phytomonitoring to evaluate the irrigation scheduling in vineyards (vitis vinifera I.) of itata valley Chile
}

\begin{abstract}
The phytomonitoring is a technology that provides information in real time of crop water status and allow to make a feedback between crop and grower to improve the irrigation control. The aim of this investigation was to asses the plant water status and your effect on yield and quality parameter in a commercial vineyard under drip irrigation in an Ultic Palexeralf soil during the 2008-2009 growing season at Central Southern of the Nuble Region, Itata Valley, Chile. The experimental design was split-plot with three treatments of soil texture: clayey loam, sandy clay and clayey, and three sub-treatments of 'Cabernet Sauvignon', 'Merlot' and 'Syrah' cultivars. Stomatal conductance, leaf-air temperature, cluster weight, berry diameter, berry weight, and soluble solids content were evaluated. The results showed that the phytomonitoring is useful to evaluate the irrigation management in vineyards. Stomatal conductance and leaf-air temperature showed good performance as indicators of vine water status and grapevine quality. This study highlight the effect of soil texture on yield and wine quality in grapevines of semi-arid zones with drip irrigation.
\end{abstract}

Volume 4 Issue 5 - 2020

\section{Celerino Quezada, Ricardo Merino, Alejandro Chandía, Marcos Cassanova \\ Faculty of Agronomy, University of Concepción, Chile}

Correspondence: Celerino Quezada, Faculty of Agronomy, University of Concepción, Chile, Tel 56-42-2208927, Email cequezad@udec.cl

Received: June 25, 2020 | Published: September 07, 2020

Keywords: stomatal conductance, leaf temperature, soil texture, yield components

\section{Introduction}

Different instruments measure various aspects of soil-water relations, but none direct assesses the portion available water to the vine. Thus, they do not provide an accurate map of the spatial and temporal variability in moisture troughout the vineyard and such variation can significantly affects vine growth and irrigation efficiency. ${ }^{1}$ Nowdays, the phytomonitoring technique allow the adquisition of a big pool of soil-plant -water data in real time, making possible a more precise estimation of vineyard water fluxes.

Phytomonitoring is a management information system for crop growing and has three main functions: generate a customized sets of measured values and their derivatives used by a grower in daily control productive, early detection of unexpected disorders in plants and decision support-system. ${ }^{2}$

This system include the moisture measurements and the development of an intelligent control system, in order to maintain the moisture level around level set, such as water stress or field capacity, according to the desired enological grape quality, in addition helps to overcome difficulties imposed by a growing water demand. ${ }^{3}$ The use of physiological parameters to asses the dynamics of plant water status has attracted the attention of many growers. This technique relates teh soil physical properties and the environmental conditions within the orchard with its effects on plant growth.

Plants express physiological responses to dynamic balance changes in the soil-plant water-environmental system and the phytomonitoring measure the plant water status, integrating the soil water availability with the air vapour pressure deficit, decreasing the effect of soil spatial variability in the management of frecuency and timing irrigation. ${ }^{4}$ This technique combines data acquisition system based on specific sensors and data processing software, which presents measuring information in terms of plant physiology and agronomy ${ }^{5}$ and has demostrated great potential for assessing vine water status. ${ }^{6}$

Water status parameters such midday stem water potential $(\Psi \mathrm{s})$, stomatal conductance $\left(\mathrm{g}_{\mathrm{s}}\right.$ and leaf-air temperature $(\mathrm{dT})$ have been used to improve the irrigation management for vineyard in arid areas. ${ }^{7}$ The infrared thermometry can be used for the irrigation scheduling of the grapevine. ${ }^{8}$ However, the variable responses of different cultivars to different climatic conditions and water stress levels make it difficult to use only one indicator for vine water status or irrigation scheduling. ${ }^{9}$ According to Cifre et al. ${ }^{7} \mathrm{~g}_{\mathrm{s}}$ is a more precise and sensitive indicator of water stress than $\Psi \mathrm{s}$ and relative water content (RWC), when mild or moderate soil water deficit is applied.

Stomatal closure is known to be a sensitive response to soil water deficit and can be used to determine the water status of plants. Direct estimation of leaf stomatal conductance to water vapor from temperature measurements, avoids the need for multiple and time consuming leaf gas-exchange measurements and allows for assessment of variation in stomatal conductance over large crop area. ${ }^{10}$

The aim of this investigation was to asses the use of stomatal conductance and leaf-air temperature on the irrigation scheduling of three grapevine cultivar under drip irrigation in an Ultic Palexeralfs at Central Southern of the Ñuble Region, Itata Valley of Chile.

\section{Materials and methods}

\section{Site experimental}

A field experiment was carried out in a commercial vineyard planted in 2004 at central-southern Chile $\left(36^{\circ} 36^{\prime} \mathrm{S}, 71^{\circ} 55^{\prime} \mathrm{W}\right.$, ) Ñuble Region, Itata Valley, in an Ultic Palexeralfs soil, during 20082009 growing season. The climate is Mediterranean with average 
annual rainfall is $1100 \mathrm{~mm}$. Annual reference evapotranspiration is reported as $1200 \mathrm{~mm}$, with a dry period of 4 to 5 months and with 5-6 frost-free months. Average annual mean temperature for this area is $13.5^{\circ} \mathrm{C}$ with an average temperature of $3.7^{\circ} \mathrm{C}$ in the coldest month (June) and $28^{\circ} \mathrm{C}$ in the hottest month (January). Annual mean relative humidity is $70 \% .^{11}$

\section{Vineyards}

The commercial vineyard (Figure 1) has a area of 50 ha divided in 13 drip irrigation sectors. The cultivars 'Cabernet Sauvignon', 'Merlot' and 'Syrah' was planted at $3 \mathrm{~m}$ between rows and $0.8 \mathrm{~m}$ between plants, trained by modificated Scott Henry system. The vines were irrigated by drip irrigation (one emitter per vine at $4 \mathrm{Lh}^{-1}$ and 10 w.c,m.). The timing varied from 1 to 4 hours and the irrigation frecuency of 1 to 2 days. The applied water volume during the growing season were $1640 \mathrm{~m}^{3} \mathrm{ha}^{-1}$ in clayey loam, $1987 \mathrm{~m}^{3} \mathrm{ha}^{-1}$ in sandy clay and $1261 \mathrm{~m}^{3} \mathrm{ha}^{-1}$ in clayey soil.

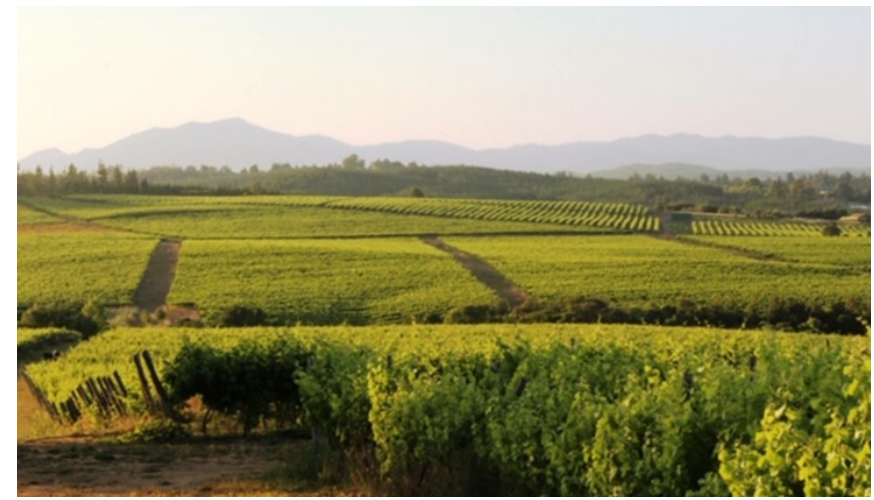

Figure I Vineyards santa cruz de bellavista farm, riveras del valle wines, Itata valley, Ñuble region, Chile.

\section{Experimental design}

The experimental design was a split-plot with three treatments of soil texture (clayey loam, sandy clay and clayey), three subtreatments: 'Merlot',' Cabernet Sauvignon' and 'Syrah' cultivars, and three replicates of 10 vines.

\section{Evaluations}

Stomatal conductance $\left(\mathrm{g}_{\mathrm{s}}\right)$ and leaf-air temperature $(\mathrm{dT})$ was measured every 15 days between 11:00 and 16:00 hr using a diffusion porometer (Delta-T AP4 Devices, Cambridge, UK) in 6 leaf per vine. At harvest, cluster weight, berry diameter and berry weight in 4 clusters per vine were measured. The equatorial diameter of 100 berry per cluster by calibrator $15-28 \mathrm{~mm}$ ( Field Instruments, Santiago, Chile) and soluble solid concentration using a thermo-compensated retract to meter $0-32^{\circ}$ Brix (Atago N-4e,Atago Co. Ltd., Atago, Japan) were measured.

\section{Statistical Analysis}

Data analysis was done by ANOVA. The comparison of treatments mean was made by the Duncan's test at $5 \%$ probability. Normality was contrasted with the Shapiro-Wilks modified. ${ }^{12}$

\section{Results and Discussion}

The gas exchange plant-atmosphere was similar during the growing season, that $g_{s}$ values in January were of 172 and $175 \mathrm{mmol}$ $\mathrm{m}^{-2} \mathrm{~s}^{-1}$ in clayey loam and clayey soil, respectively and $179 \mathrm{mmol} \mathrm{m}^{-2}$ $\mathrm{s}^{-1}$ in sandy clay soil (Figure 2). However, November showed greater values of $g_{s}$ in three soil textures due to low crop evapotranspiration $(24 \mathrm{~mm})$ as compared with critical month $(113 \mathrm{~mm})$. An optimum threshold for $\mathrm{g}_{\mathrm{s}}$ ranged between 50 and $150 \mathrm{mmol} \mathrm{m}^{-2} \mathrm{~s}^{-1}$ is adequate to increase water use efficiency in grapevines. ${ }^{12}$

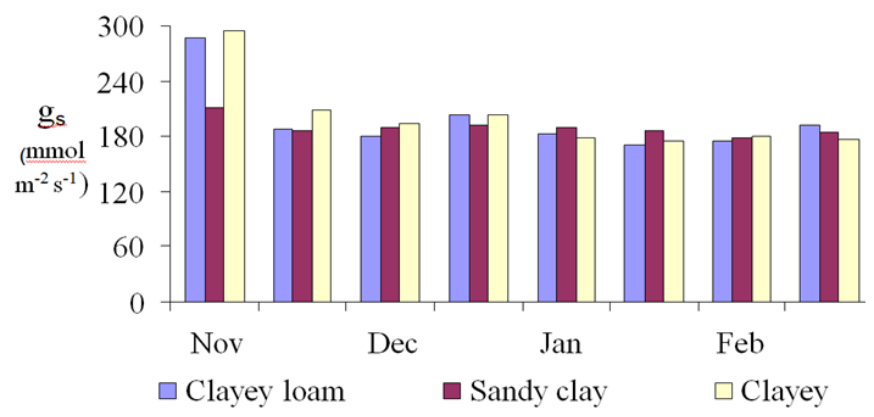

Figure 2 Stomatal conductance $\left(\mathrm{g}_{\mathrm{s}}\right)$ in grapevine with drip irrigation in three soil texture of an Ultic Palexeralfs during the growing season.

Regarding soil texture, the lower $\mathrm{g}_{\mathrm{s}}$ was found in sandy clay (193 mmol m $\mathrm{m}^{-2} \mathrm{~s}^{-1}$ ) that indicate a mild water stress in comparison with clayey loam $\left(208 \mathrm{mmol} \mathrm{m}^{-2} \mathrm{~s}^{-1}\right)$ and clayey soil $\left(205 \mathrm{mmol} \mathrm{m}^{-2} \mathrm{~s}^{-1}\right)$ (Figure 3), probably because the applied water volume was lower $\left(1987 \mathrm{~m}^{3} \mathrm{ha}^{-1}\right)$ that the vine water requirements . Besides, the sandy soils have lower water-holding capacity that decreased the leaf gas exchange. ${ }^{13}$

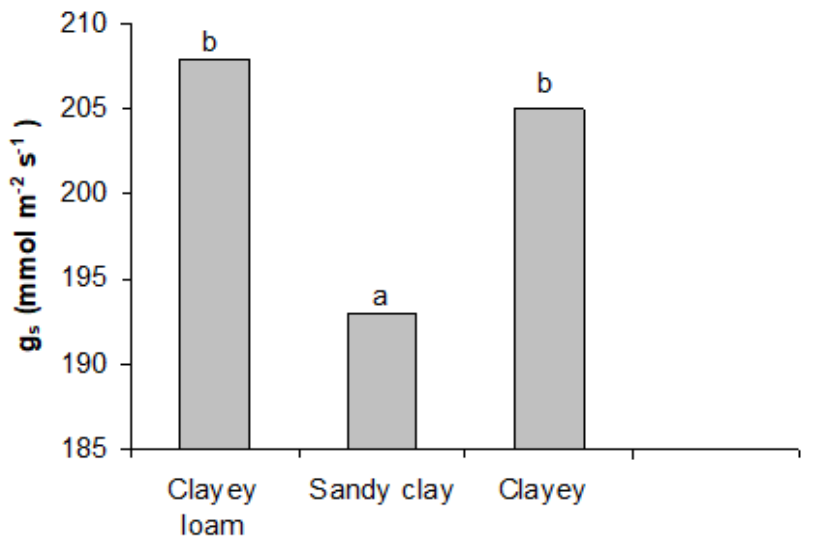

Figure 3 Stomatal conductance $\left(g_{s}\right)$ in grapevine with drip irrigation in three soil texture of an Ultic Palexeralfs. Differents letters on each column indicate significant differences at $\mathrm{p} \leq 0.05$ ) according Duncan's test.

Regarding cultivars 'Cabernet Sauvignon', 'Merlot' and 'Syrah' showed significative differences $(\mathrm{p}<0.05)$ of gs in three soil texture (Figure 4) indicating a differential response to edapho-climatic conditions and the applied water volume, that will be associated with the stomatal performance ${ }^{14}$ and drought-resistant cultivar. ${ }^{15}$ Consequently, 'Merlot' had the best performance in clayey due to greater water availability $(11,25 \%)$, but for Cabernet Sauvignon and Syrah was obtained in sandy clay texture due to anisohydric stomatal behavior. ${ }^{16}$ However, Levin et al. ${ }^{17}$ showed that V. vinifera cultivars possess both iso- and anisohydric stomatal behaviours that depend on the intensity of water deficits, and call into question previous classifications assuming a single behaviour.

These results remarks the effect of soil texture and cultivars in the 
stomatal conductance with values between $150-250 \mathrm{mmol} \mathrm{m}^{-2} \mathrm{~s}^{-1}$ that is in accordance with Medrano et al..$^{14}$ who showed values between 60 and $200 \mathrm{mmol} \mathrm{H}_{2} \mathrm{O} \mathrm{m}^{-2} \mathrm{~s}^{-1}$, which would correspond to severe when drops below $50 \mathrm{mmol} \mathrm{H} \mathrm{O} \mathrm{m}^{-2} \mathrm{~s}^{-1}$, moderate between 50 and $150 \mathrm{mmol} \mathrm{H}_{2} \mathrm{O} \mathrm{m}^{-2} \mathrm{~s}^{-1}$ and mild typically $200-500 \mathrm{mmol} \mathrm{H}_{2} \mathrm{O} \mathrm{m}^{-2} \mathrm{~s}^{-1}$ in grapevines water stress. ${ }^{14,18}$ The thresold level in grapevines would be $200 \mathrm{mmol} \mathrm{m}^{-2} \mathrm{~s}^{-1}$ for mild stress in the three types of soil, but Cabernet, Sauvignoin and Syrah it have a better adaptation on sandy clay and Merlot on clayey soil (Figure 4). This is in ccordance with Quezada et al. ${ }^{19}$ who remarked the influence of soil physical properties in the selection of sites with viticultural aptitude incuding cultivars.

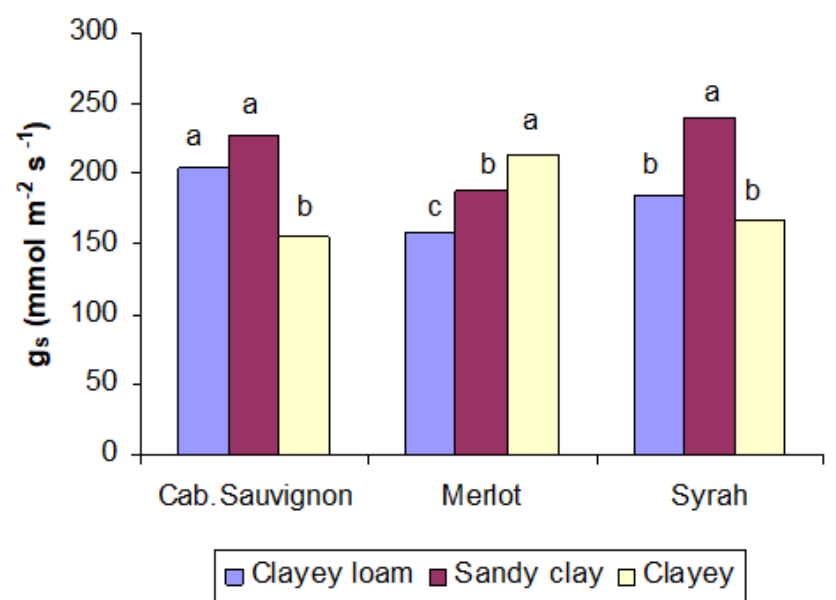

Figure 4 Stomatal conductance $\left(\mathrm{g}_{\mathrm{s}}\right)$ in grapevine 'Cabernet-Sauvignon', 'Merlot' y 'Syrah' with drip irrigation in three soil texture of an Ultic Palexeralfs. Differents letters on each column indicate significant differences at $\mathrm{p} \leq 0.05$ ) according Duncan's test.

Regarding leaf-air dT $\left({ }^{\circ} \mathrm{C}\right)$, the vines showed positive values in December and January about $1,4^{\circ} \mathrm{C}$ in the sandy clay (Figure 5) indicating temporary and mild water stress due to lower water-holding capacity of the soil. ${ }^{13}$

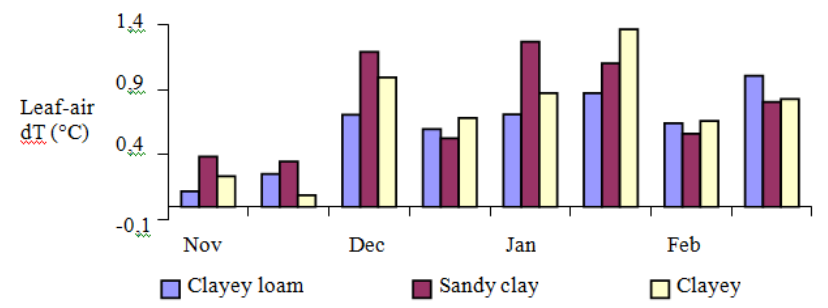

Figure 5 Leaf-air dT $\left({ }^{\circ} \mathrm{C}\right)$ in grapevine with drip irrigation in three soil texture of an Ultic Palexeralfs during the growing season.

The effect of soil texture was significative $(p \leq 0,05)$ on the leaf-air dT (Figure 6) with positive values in sandy clay $\left(0,8^{\circ} \mathrm{C}\right)$ that indicating mild water stress in comparison with vines planted in clayey loam and clayey soil. This is in accordance with the results of $g_{s}$, due to lower water availability of sandy clay $(7,0 \%)$ as compared with clayey loam $(8,4 \%)$ and clayey soil $(11,25 \%)$. According to Ubalde et al. ${ }^{20}$ the soil properties related to soil moisture regime have a direct influence on vineyard management and grape quality.

The cultivars, 'Merlot' and 'Syrah" showed higher leaf-air dT in sandy clay soil due to lower soil water availability, but in Cabernet
Sauvignon dT was lower in clayey loam (Figure 7) .In general, the cultivars revealed the best response to irrigation management in clayey loam texture, that the leaf-air dT was $0.6^{\circ} \mathrm{C}$ probably due to greater wetted soil volume. However, the higher leaf-air dT was found in sandy clay texture, that indicate mild water stress and the need of improve the irrigation scheduling.

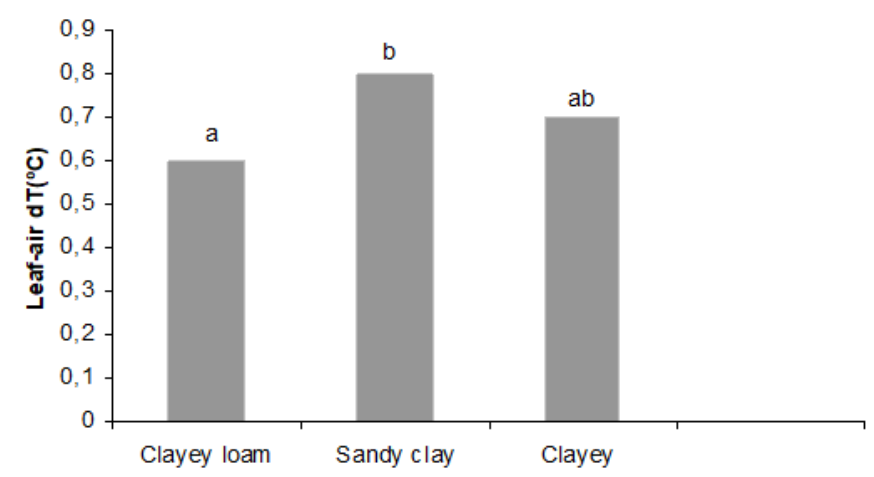

Figure 6 Leaf-air dT $\left({ }^{\circ} \mathrm{C}\right)$ in grapevine with drip irrigation in three soil texture of an Ultic Palexeralfs soil. Differents letters on each column indicate significant differences at $\mathrm{p} \leq 0.05$ ) according Duncan's test.

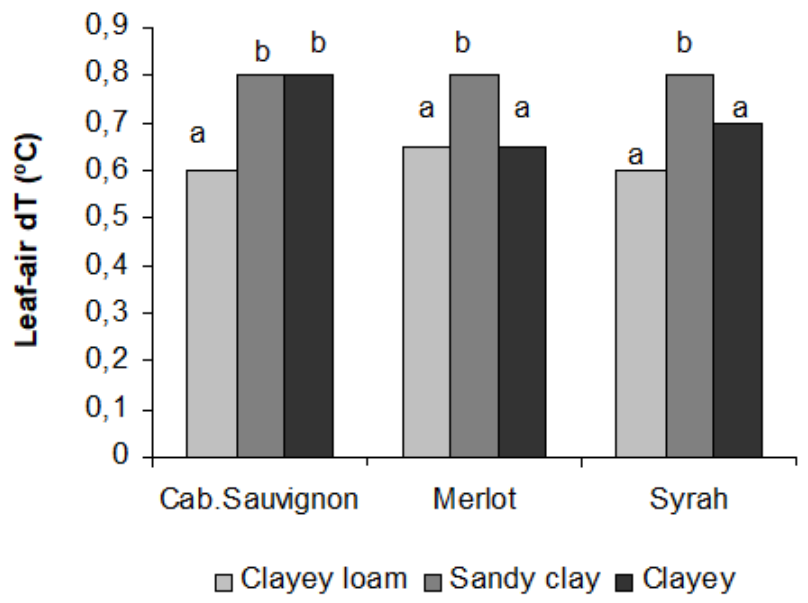

Figure 7 Leaf-air dT $\left({ }^{\circ} \mathrm{C}\right)$ in grapevine 'Cabernet Sauvignon', 'Merlot' y 'Syrah' with drip irrigation in three soil texture of an Ultic Palexeralfs. Differents letters on each column indicate significant differences at $p \leq 0.05$ according Duncan's test.

Concerning yields components, cluster weight showed significant differences with the soil texture $(\mathrm{p}<0.05)$ only for 'Cabernet Sauvignon' (Table 1), showed lower values in sandy clay texture, due to the minor number of berries per cluster and low water availability (7\%). Respect to berry weight, only 'Cabernet Sauvignon' not showed significant effects, but in berry diameter the soil texture had significant effect on the three cultivars.

The soil texture had significant effects $(p<0,05)$ in the wine quality of 'Merlot' and 'Cabernet Sauvignon' with maximum 'Brix in sandy clay soil (Table 1) due to the effect of water stress in advanced fruit maturation. ${ }^{21}$ On the other hand, 'Syrah' not showed significant differences in ${ }^{\circ}$ Brix with the soil texture, according with results obtained by Reynolds et al. ${ }^{16}$ with different irrigation regimes. ${ }^{22}$ 
Table I Yield components and quality of grapevine 'Cabernet Sauvignon', 'Merlot' and 'Syrah' with drip irrigation in three soil texture of an Ultic Palexeralfs. Differents letters in the same column indicate significant differences at $\mathrm{p} \leq 0.05$ according Duncan's test

\begin{tabular}{|c|c|c|c|c|c|c|c|c|c|c|c|}
\hline \multirow[t]{2}{*}{ Soil texture } & \multicolumn{3}{|c|}{ Cluster weight (g) } & \multicolumn{3}{|c|}{ Berry weight (g) } & \multicolumn{2}{|c|}{ Berry diameter $(\mathrm{mm})$} & \multicolumn{3}{|c|}{ Soluble solids ( ${ }^{\circ}$ Brix) } \\
\hline & CS & ME & SY & CS & ME & SY & ME & SY & CS & ME & SY \\
\hline Clayey loam & $98,8 \mathrm{~b}$ & $92,4 a$ & $91,5 \mathrm{a}$ & $\mathrm{I}, \mathrm{la}$ & $\mathrm{I}, 2 \mathrm{~b}$ & $\mathrm{I}, \mathrm{I} \mathrm{ab}$ & $12,5 b \mid 2,6 b$ & $12,9 a b$ & $26,0 \mathrm{ab}$ & $23,6 a$ & $25,2 \mathrm{a}$ \\
\hline Sandy clay & 82,5 a & 107,0 a & 76,8 a & $\mathrm{I}, \mathrm{Ia}$ & $\mathrm{I}, 0 \mathrm{~b}$ & $\mathrm{I}, 2 \mathrm{~b}$ & $12,2 a \quad 12,4 a$ & $13,1 \mathrm{~b}$ & $27,0 \mathrm{~b}$ & $25,6 \mathrm{c}$ & $24,4 a$ \\
\hline Clayey & $97,6 \mathrm{~b}$ & $105,7 \mathrm{a}$ & $79,8 \mathrm{a}$ & $\mathrm{I}, \mathrm{Ia}$ & $\mathrm{I}, \mathrm{lab}$ & $\mathrm{I}, 0 \mathrm{a}$ & $12,2 \mathrm{a} \quad \mid 2,4 \mathrm{a}$ & $12,8 \mathrm{a}$ & $24,9 a$ & $24,7 b$ & $24,3 a$ \\
\hline
\end{tabular}

CS, cabernet sauvignon; ME, merlot; SY, syrah

\section{Conclusion}

The results showed that the phyto monitoring is useful to evaluate the irrigation managementin vine yards. Stomatal conductance and leaf-air temperature diferencial showed good performance as indicators of vine water status and berry quality. This study highlight the influence of soil texture on yield and wine quality in grapevines of mediterranean areas irrigated by drip irrigation. The stomatal conductance thresh. old determined in this investigation was $200 \mathrm{mmol}$ $\mathrm{m}^{-2} \mathrm{~s}^{-1}$ as indicator of good scheduling irrigation.

\section{Acknowledgments}

None.

\section{Conflicts of interest}

Authors declare no conflict of interest exists.

\section{References}

1. Jackson R. Wine science. Principles and applications. Fourth edition. Academic Pres Elsevier, San Diego, CA. USA. 2014

2. Channarayappa, Biradar DP. Soil basics, management and rizhosphere engineering for sustainable agriculuture. CRC Press. 2019.

3. Capraro F, Schugurensky C, Vita F, et al. Intelligent irrigation in grapevines: a way to obtain different wine characteristics. Proceedings of the 17th World Congress. The International Federation of Automatic Control. 2008;2950-2955.

4. Bonany J, Camps F, Salvia J, et al. Relationship between trunk diameter fluctuations, stem water potential and fruit growth rate in potted adult apple trees. Acta Hortic. 2000;511:43-49.

5. Ton Y, Nilov N, Kopyt M. Phytomonitoring: the new information technology for improving crop production. Acta Hortic. 2001;562:257262.

6. Ton Y, Kopyt M. Phytomonitoring in realization of irrigation strategies for wine crops. Acta Hortic. 2004;652:167-173.

7. Cifre J, Bota J, Escalona JM, et al. Physiological tools for irrigation scheduling in grapevine (Vitis vinifera L.): An open gate improves water-use efficiency?. Agric Ecosyst Environ. 2005;106:159-170.

8. Anconelli S, Battilani A. Use of leaf temperature to evaluate grapevine (Vitis vinifera) yield and quality response to irrigation. Acta Hortic. 2000;537:407-413.
9. Romero P, Fernández-Fernández JI, Martinez-Cutillas A. Physiological thresholds for efficient regulated deficit-irrigation management in winegrapes grown under semiarid conditions. Am J Enol Vitic. 2010;61:300-312.

10. Pou A, Diago MP, Medrano H, et al. Validation of thermal indices form water status identification in grapevine. Agric Water Manage. 2014;134(1):60-72.

11. Pozo del A, del Canto P. Áreas agroclimáticas y sistemas productivos en la VII y VIII regiones, Serie Quilamapu No113, INIA Quilamapu, Chillán, Chile. 1999.

12. SAS Institute. The SAS systems for windows. [CD-Rom] Vers. 8. SAS. Institute Cary, North Carolina, USA. 1999.

13. Leeuwen van $C$, Friant $P$, Choné $X$, et al. Influence of climate, soil, and cultivar on terroir. Am J Enol Vitic. 2004;55: 207-217.

14. Medrano H., Escalona JM, Bota J, et al. Regulation of photosynthesis of $\mathrm{C} 3$ plants in response to progressive drought :stomatal conductance as a reference parameter. Annals of Botany. 2002;89(7):895-905.

15. Schultz HR. Differences in hydraulic architecture account for nearisohydric and anisohydric behaviour of twofield-grown Vitis vinifera L. culivars during drought. Plant Cell Environ. 2003; 26:1393-1405.

16. Reynolds AG, Sorokowsky D, Gensler, W. Evapotranspiration-based irrigation scheduling for Syrah: assessing vine water status by petiole electrical potential. Am J Enol Vitic. 2012;63:343-356.

17. Levin AD, Williams LE, Matthews A. A continuum of stomatal responses to water deficits among 17 wine grape cultivars (Vitis vinifera L.). Functional Plant Biology AN. 2019;47(1):11-25.

18. Bota J, Tomas M, Flexas J, et al. Differences among grapevine cultivars in their stomatal behavior and water use efficiency under progressive water stress. Agric Water Manage. 2016;164:91-99.

19. Quezada C, Soriano MA, Diaz J, et al. Influence of soil physical properties on the selection of sites with vitivultural aptitude. Open Journal of Soil Science. 2014;4:127-135

20. Ubalde JM, Sort X, Poch RM. How soil forming processes determine soil-based viticultural zoning. J Soil Sci Plant Nutr. 2011;11:100-126.

21. Bowen P, Bogdanoff C, Estergaard B. Effects of converting from sprinkler to drip irrigation on water conservation and the performance of Merlot grown on a loamy sand. Am J Enol Vitic. 2012;63:385-393.

22. Gurovich LA, Ton Y, Vergara LM. Irrigation scheduling of avocado using phytomonitoring techniques. Cien Inv Agr. 2006;33(2):117-124. 